\title{
Photocatalytic degradation of caffeine and $E$. coli inactivation using silver oxide nanoparticles obtained by a facile green co-reduction method
}

Harshiny Muthukumar ( $\sim$ harshiny37@gmail.com )

Indian Institute of Technology Madras

Santosh Kumar Palanirajan

Indian Institute of Technology Madras

Manoj Kumar Shanmugam

Indian Institute of Technology Madras

Arivalagan Pugazhendhi

Ton Duc Thang University

Sathyanarayana N. Gummadi

Indian Institute of Technology Madras

\section{Research Article}

Keywords: Silver oxide, Photocatalytic degradation, Caffeine, E. coli, Antibacterial, Inactivation

Posted Date: April 30th, 2021

DOl: https://doi.org/10.21203/rs.3.rs-245921/v1

License: (9) This work is licensed under a Creative Commons Attribution 4.0 International License. Read Full License

Version of Record: A version of this preprint was published at Clean Technologies and Environmental Policy on June 11th, 2021. See the published version at https://doi.org/10.1007/s10098-021-02135-7. 


\section{Abstract}

In this study, silver oxide nanoparticles ( $\left.\mathrm{Ag}_{2} \mathrm{O}-\mathrm{NPs}\right)$ were synthesized from silver nitrate using green amaranth leaf extract as reducing agent. The degradation of caffeine and inactivation of Escherichia coli by $\mathrm{Ag}_{2} \mathrm{O}-\mathrm{NPs}$ was studied under compact fluorescent lamp illumination irradiation. Apart from that, the antibacterial and antioxidant activities of $\mathrm{Ag}_{2} \mathrm{O}-\mathrm{NPs}$ were also examined. Synthesized $\mathrm{Ag}_{2} \mathrm{O}-\mathrm{NPs}$ were shaped like monodispersed husk, and cubic structured with surface area and average particle size was detected to be $100.21\left(\mathrm{~m}^{2} / \mathrm{g}\right)$ and $81 \mathrm{~nm}$ respectively. Antioxidant efficacy of the $\mathrm{Ag}_{2} \mathrm{O}-\mathrm{NPs}$ was evaluated using 1, 1-diphenyl-2-picrylhydrazyl and $91 \%$ inhibition was achieved with $100 \mu \mathrm{g} \mathrm{Ag}_{2} \mathrm{O}-\mathrm{NPs}$. Bacteriocidic propensity of $\mathrm{Ag}_{2} \mathrm{O}-\mathrm{NPs}$ was examined against the $S$. aureus and $P$. aeruginosa by disc diffusion, minimum inhibitory concentration (MIC), Live and dead assay. It was observed that the NPs have higher bactericidal effect on Gram-negative as compared to Gram-positive bacteria. Up to $96 \%$ photocatalytic inactivation of $E$. coli was achieved using $30 \mu \mathrm{g} / \mathrm{mL}$ of NPs, Photocatalytic degradation of caffeine (50 ppm initial concentration) was observed to be $99 \%$ at pH 9 in $15 \mathrm{~h}$ using $50 \mathrm{mg} / \mathrm{L}$ of $\mathrm{Ag}_{2} \mathrm{O}$ NPs. These results indicate that $\mathrm{Ag}_{2} \mathrm{O}$ NPs can be employed in environmental applications like harmful bacteria inactivation and organic pollutants degradation.

\section{Introduction}

The rising rate of drug-resistance to current antibiotics microbial infections and adverse toxic effects of some antibiotics warranted alternative of new drugs (Wang et al. 2018; Roy et al. 2019). In this regard, nanotechnology is a forthcoming research topic in area of infectious disease treatment with the advancement of nano-scale substances with enhanced antimicrobial activities against multidrugresistant microbes (Shanmuganathan et al. 2018). Among the nanomaterials, metal nanoparticles (NPs) give the maximum effective outcome. Currently, several NPs for instance $\mathrm{Ag}, \mathrm{Ag}_{2} \mathrm{O}, \mathrm{Au}, \mathrm{Cu}, \mathrm{CuO}, \mathrm{CeO}_{2}, \mathrm{Fe}$, $\mathrm{FeO}, \mathrm{TiO}_{2}$ and $\mathrm{ZnO}$ are synthesized via several methods and have several applications such as applied as antimicrobial and anticancer agents, as catalysts, cosmetic, coatings and in nano-device (Schröfel et al. 2014; Aiswarya Devi et al. 2017; Pugazhendhi et al. 2018). However, the application of NPs was limited in real-time usages, such as clinical, environmental remediation/reclamation, water treatment material, etc., primarily due to the physicochemical properties of NPs such as low solidity, high solubility, monodispersity, wide bandgap, and adverse noxious effect (Kahru and Dubourguier 2010).

It has been reported that nanosized silver particles (size $<100 \mathrm{~nm}$ ), hold high stability, surface-area-tovolume ratio, have a bandgap of $1.3 \mathrm{eV}$ and are less toxicity (Jiang et al. 2015). Silver nanoparticles been extensively used as antimicrobial and drug delivery agents as well as more efficient photocatalyst under visible light compared to many other metal oxides (Yang et al. 2015). Till date, NPs have been prepared by physical, chemical, electrochemical, sonochemical, irradiation, and biological routes (Iravani, S, Korbekandi, H, Mirmohammadi, SV, Zolfaghari 2014). Use of plant sources in synthesis of nanoparticles offers several advantages from previously documented process since this process is biocompatible, nontoxic, non-hazardous, economical, eco-friendly, and sustainable. Moreover, plant sources satisfy the roles 
of stabilizing, reducing, and capping materials (Ahmed et al. 2016; Elemike et al. 2017). The extract of various plants has been used for the biosynthesis of NPs (Siddiqi et al. 2018). Among the plant extracts studied, aqueous leaf extracts of Amaranthus. sp. hold many organic compounds and have been used for the synthesis of NPs (Muthukumar et al. 2020a).

The choice of microbes in the current study was based on noxious traits toward human health. Staphylococcus aureus is a Gram-positive (+ve), round bacterium which is the causal agent of pulmonary infections and urinary tract infections(Taylor, and Unakal 2019). Pseudomonas aeruginosa is a Gram-negative (-ve), rod-shaped bacterium and a multidrug-resistant pathogen implicated in nosocomial infections, external ear canal infection (Pang et al. 2019). It is also imperative to improve characteristics of visible-light-driven bactericidal photocatalysts (Ren et al. 2009; Ganguly et al. 2018). The identification of harmful nano technology and materials used for synthesis of nano particles and also confirming the techniques and materials described as harmless is essential in exploring new applications of nanoparticles (Nel et al. 2010).

Currently, pharmaceuticals and personal care product have gained inattention as emerging micropollutants threats to the marine environment and human health. Among that, Caffeine has been detected in surface water worldwide and being used as a chemical marker for surface water pollution. Also, it is very hard to remove and degrade by conventional treatment methods. It was reported that, the green mediated semiconductors photocatalysis and ability to utilize light source was recognized to be an efficient technology for wastewater treatment [20].

Based on the above considerations, in this study, $\mathrm{Ag}_{2} \mathrm{O}-\mathrm{NPs}$ have been produced using aqueous leaf extract of green amaranth as a reducing and capping agent. The morphology, composition and structural characteristic of synthesized $\mathrm{Ag}_{2} \mathrm{O}-\mathrm{NPs}$ were analyzed. Further, antioxidant activity of $\mathrm{Ag}_{2} \mathrm{O}-\mathrm{NPs}$ was estimated by 2,2-diphenyl-1-picrylhydrazyl (DPPH) assay. Cytotoxicity of the synthesized $\mathrm{Ag}_{2} \mathrm{O}-\mathrm{NPs}$ was tested against human embryonic kidney (non-cancerous) cells (HEK 293T) by (3-(4,5-dimethylthiazolyl2)-2,5-diphenyltetrazolium bromide) MTT assay. Antibacterial activity of $\mathrm{Ag}_{2} \mathrm{O}-\mathrm{NPs}$ was examined against the $S$. aureus and $P$. aeruginosa by disc diffusion, minimum inhibitory concentration (MIC) and Live and dead assay. The photocatalytic inactivation and degradation of $E$. coli and caffeine using leaf extract mediated $\mathrm{Ag}_{2} \mathrm{O}-\mathrm{NPs}$ under compact fluorescent lamp irradiation were also studied.

\section{Experimental Methods}

\subsection{Materials}

Chemicals such as ascorbic acid, DPPH, dimethyl sulfoxide (DMSO), kanamycin, silver nitrate $\left(\mathrm{AgNO}_{3}\right)$, nutrient broth, and agar-agar were obtained from Merck and Himedia Laboratories (Mumbai, India). Bacterial strains E. coli (MTCC 7410), P. aeruginosa (MTCC-2488) and S. aureus (MTTC 424) were obtained from the Microbial Type Culture Collection, Chandigarh, India. 


\subsection{Synthesis of nanoparticles}

For synthesis of $\mathrm{Ag}_{2} \mathrm{O}-\mathrm{NPs}, 1 \mathrm{mM}$ silver nitrate $\left(\mathrm{AgNO}_{3}\right)$ solution and $20 \mathrm{~g}$ aqueous leaf extract were used as source of $\mathrm{Ag}^{+}$ions and reducing mediator respectively. Leaf extract was prepared as per the previous reported protocol (Muthukumar et al. 2020a). $25 \mathrm{ml}$ of leaf extract solution (pH 6.0) was slowly added to $75 \mathrm{~mL} \mathrm{\textrm {ANO } _ { 3 }}$ solution for $15-20 \mathrm{~min}$ at $35 \pm 2{ }^{\circ} \mathrm{C}$ under continuous stirring using a magnetic stirrer. Formation of $\mathrm{Ag}_{2} \mathrm{O}-\mathrm{NPs}$ was indicated by change in color of precursor solution from colorless to brown. The obtained particles were centrifuged at 12,000 rpm for $20 \mathrm{~min}$ and washed three times with Milli-Q $\mathrm{H}_{2} \mathrm{O}$ followed by drying at $100 \pm 2{ }^{\circ} \mathrm{C}$. Finally, the obtained particles were kept in a hermetically sealed bottle for future use.

\subsection{Characterization techniques}

Crystal structure of $\mathrm{Ag}_{2} \mathrm{O}-\mathrm{NPs}$ was investigated using a X-ray diffractometer (PANalyticalX'per PRO) equipped with a Cu Ka radiation $(I=1.5406 \AA)$ at $2.2 \mathrm{~kW}$ Max. Morphological features of NPs were studied using a scanning electron microscope (SEM Carl Zeiss Evo 18 Germany) and the images were captured at $20 \mathrm{kV}$. Fourier transform infrared spectroscopy (FTIR) analysis of aqueous leaf extract and NPs was carried out at a scan range of $4000-400 \mathrm{~cm}^{-1}$ and scanning speed of $2 \mathrm{~mm} \mathrm{~s}^{-1}$ on a IR Pestige21 instrument (Shimadzu). Size and zeta potential of NPs were evaluated using Malvern Zetasizer (Ver. 7.02, Malvern Instruments Ltd) dynamic light scattering (DLS) technique. Stained LIVE/DEAD bacterial cells were observed under an ECLIPSE 80i fluorescence microscope (Nikon, Japan) with Spot-K slider CCD camera (Diagnostic Instruments Inc., USA).

\subsection{Antimicrobial and antioxidant activity}

The bactericidal activity of $\mathrm{Ag}_{2} \mathrm{O}-\mathrm{NPs}$ against $S$. aureus and $P$. aeruginosa was tested via disk diffusion susceptibility and minimum inhibitory concentration method. Also, antioxidant activity of leaf aqueous extract and NPs were confirmed by DPPH assay. Likewise, the NPs MTT cytotoxicity assay against HEK 293T was carried out as per the previously reported protocol (Muthukumar et al. 2020a, b). All the experiments were conducted in triplicate and statistical significance of the tests was evaluated using software GraphPad Prism (La Jolla, USA).

\subsection{Live and dead assay}

Live and dead assay was conducted to examine the bactericidal effect of $\mathrm{Ag}_{2} \mathrm{O}-\mathrm{NPs}$. For this, 30 $\mu \mathrm{g} / \mathrm{mL}$ of $\mathrm{Ag}_{2} \mathrm{O}-\mathrm{NPs}$ in solution was loaded into test bacterial culture at $10^{5} \mathrm{CFU} \mathrm{ml}^{-1}$ concentration and incubated at $37^{\circ} \mathrm{C}$ for $24 \mathrm{~h}$. The suspension of bacterial cells was centrifuged and the pellet was resuspended in liquid broth medium $(1 \mathrm{~mL})$. The cells were incubated for $10 \mathrm{~min}$ at $37^{\circ} \mathrm{C}$ with $5 \mathrm{mg} / \mathrm{mL}$ of acridine orange and $3 \mathrm{mg} / \mathrm{mL}$ propidium iodide. This was followed by centrifugation of the incubated cell suspension at $7000 \mathrm{rpm}$ for $7 \mathrm{~min}$ at $4{ }^{\circ} \mathrm{C}$. Supernatant was discarded and the unbonded dyes were removed using $1 \times$ phosphate-buffered saline at $\mathrm{pH}$ 7.4. The cell suspension $(\sim 5 \mu \mathrm{L})$ was poured on a 
glass slide and covered with the coverslip and cellular images were observed under laser confocal microscopy (Nikon Al (P)) (Thiyagarajan et al. 2018).

\subsection{Photocatalytic inactivation property of $\mathrm{Ag}_{2} \mathrm{O}-\mathrm{NPs}$}

The photocatalytic inactivation $(\mathrm{PCl})$ of $\mathrm{Ag}_{2} \mathrm{O}-\mathrm{NPs}$ was estimated on the deactivation of $E$. coli under compact fluorescent lamp (CFL) illumination at a concentration of $30 \mu \mathrm{g} / \mathrm{mL}$. E. coli culture was prepared by inoculating bacteria in Lysogeny Broth (LB) medium followed by overnight incubation at $37^{\circ} \mathrm{C} . \mathrm{PCl}$ experiments were conducted in an incubator with CFL illumination of $85 \mathrm{~W}(4 \mathrm{U}), 650 \mathrm{~mA}$ current, and 50 $\mathrm{Hz}$ frequency which was positioned at $15 \mathrm{~cm}$ atop the cell suspension. The tests were conducted in Erlenmeyer's flasks for $15 \mathrm{~h}$ at $37 \pm 1{ }^{\circ} \mathrm{C}$ with continuous agitation at $120 \mathrm{rpm}$. To know the growth kinetics of E. coli $0.5 \mathrm{~mL}$ culture samples were collected at one-hour interval and optical density of collected samples was measured at $600 \mathrm{~nm}$ by UV-Visible spectrometer. For comparison, experiments were also performed under dark and light conditions.

\subsection{Photocatalytic degradation}

Photocatalytic degradation of caffeine by NPs was studied under CFL irradiation. Caffeine solution (pH-9.0) containing 50 ppm of caffeine was added to $50 \mathrm{mg} / \mathrm{L}$ of $\mathrm{Ag}_{2} \mathrm{O}-\mathrm{NPs}$ and maintained at $37 \pm 1^{\circ} \mathrm{C}$ for $15 \mathrm{~h}$ under $\mathrm{CFL}$. At regular intervals of time, $0.5 \mathrm{~mL}$ sample was collected and centrifuged for $15 \mathrm{~min}$ at $7000 \mathrm{rpm}$. The centrifuged samples were filtered using a Millipore syringe and analysed for caffeine using HPLC at the regular time interval as per protocol described earlier (Muthukumar et al. 2020b).

\section{Results And Discussion}

\subsection{UV-Vis spectroscopic study}

The formation of the reduced $\mathrm{Ag}_{2} \mathrm{O}-\mathrm{NPs}$ (maximum $\lambda$ ), $\mathrm{AgNO}_{3}$, and leaf extract was detected using UVvisible spectrophotometer at $200-700 \mathrm{~nm}$ (Fig. $1 \mathrm{~A}$ ). In case of $\mathrm{AgNO}_{3}$ solution a broad absorption band in the wavelength region from $290 \mathrm{~nm}$ to $400 \mathrm{~nm}$ centred at $320 \mathrm{~nm}$ was observed (Fig 1A). UV-Vis spectra of the $\mathrm{AgNO}_{3}$ solution displayed a small peak around $217 \mathrm{~nm}$ which could be attributed to $\mathrm{Ag}+$ ions. Similar results were obtained for leaf extract spectra in earlier studies where polyphenol peak around 220 and a broad peak around $250 \mathrm{~nm}$ was observed (Palomares et al. 2013). The UV-visible spectra exhibited a distinct peak at $432 \mathrm{~nm}$ and it was due to the surface plasmon resonance (SPR) of $\mathrm{Ag}_{2} \mathrm{O}-\mathrm{NPs}$ and the peak at $278 \mathrm{~nm}$ could be due to oxidized polyphenols in NPs (Fig. 1A). Absorption 
peak of metal NPs is conquered by the SPR of leaf extract reduced silver ions $\left(\mathrm{Ag}^{+}\right)$to the $\mathrm{Ag}_{2} \mathrm{O}-\mathrm{NPs}$ (Rokade et al. 2016).

\subsection{IR spectral analysis of $\mathrm{Ag}_{2} \mathrm{O}-\mathrm{NPs}$}

The FTIR spectra of $\mathrm{Ag}_{2} \mathrm{O}-\mathrm{NPs}$ and green amaranth leaf extract have been given in Fig 1B. The broad peak at $3330 \mathrm{~cm}^{-1}$ indicates the existence of $(\mathrm{NH})$ amine and $(\mathrm{OH})$ hydroxyl group stretching of amaranthine and phenolic compounds respectively. Peaks at 1646, 1450, 1320, 1089, and $850 \mathrm{~cm}^{-}$

${ }^{1}$ denote the existence of aldehyde $\triangle \mathrm{C}-\mathrm{H}$ stretch, $\mathrm{C}-\mathrm{H}$ alkane stretch, $\mathrm{N}-\mathrm{O}$ (nitro) stretch $\mathrm{N}-\mathrm{H}$ and carbonyl group C-O, respectively. The detected peaks were mostly ascribed to phyto-compounds of leaf extract. These phytochemicals have been shown to play a vital role in the formation of NPs (Aiswarya Devi et al. 2017). The presence of $1029 \mathrm{~cm}^{-1} 1373 \mathrm{~cm}^{-1}$ and $1601 \mathrm{~cm}^{-1}$ peaks indicates $\mathrm{C}-\mathrm{O}, \mathrm{C}-\mathrm{H}, \mathrm{C}-\mathrm{O}$ groups in the molecule. Also, amaranthine and phenolic compounds present on the extract can donate hydroxyl and amines functional groups, so free carboxylic or amino moieties can bind to free Ag surface (Muthukumar and Matheswaran, 2015). FT-IR spectrum of the dried biosynthesized NPs showed peaks at $588 \mathrm{~cm}^{-1}$ which can be attributed to the vibration of $\mathrm{AgO}$ and thereby confirming presence of silver oxide in the prepared sample (Ravichandran et al. 2016).

\subsection{Structural, shape and size analysis}

To confirm the structure and crystallinity of the obtained $\mathrm{Ag}_{2} \mathrm{O}$ NPs, XRD analysis was used in further analysis. Fig. $1 \mathrm{C}$ shows the XRD pattern recorded from the powder sample of $\mathrm{Ag}_{2} \mathrm{O}$. Braggs reflections $2 \theta$ peaks were observed at $32.9^{\circ}, 38.2^{\circ}, 55.1^{\circ}, 66.0^{\circ}, 69.2^{\circ}$ which correspond to (111), (200), (220), (311), and (222) planes of $\mathrm{Ag}_{2} \mathrm{O}$ respectively. The observed XRD data were matched to the XRD standard data JCPDS file No. 41-1104 and assigned to the planes of the cubic $\mathrm{Ag}_{2} \mathrm{O}$ phase (Rokade et al. 2016). The diffractogram showed that synthesized NPs were crystalline cubic structure and the slight modification in intensity could be due to binding of leaf extract biomolecules to the surface of NPs (Muthukumar et al. 2020a). The chemical state of synthesized NPs has been investigated using by XPS analysis. The XPS spectrum of synthesized NPs was observed in Fig 1C, the peaks of $C 1 \mathrm{~s}$, and 01 s are observed at 284.8 and $529.5 \mathrm{eV}$. The visible peaks at 368.5 and $374.5 \mathrm{eV}$ can be ascribed to $\mathrm{Ag}+\mathrm{Of}^{\mathrm{Ag}} \mathrm{O}_{2} \mathrm{O}$ was observed in XPS survey spectra. Also, high resolution scans of Ag XPS spectra depicted the appearance of small $\mathrm{Ag}^{0}$ peaks at 369 and $375 \mathrm{eV}$ (data not shown). The XPS examination results visibly showed the co-existence of $\mathrm{Ag}^{\mathrm{O}}$ and $\mathrm{Ag}_{2} \mathrm{O}$. Xu et al., reported that solvent free $\mathrm{Ag} / \mathrm{Ag}_{2} \mathrm{O}$ nanocomposites show high photocatalytic activity and suitable for practical application of water treatment under the visible-light irradiation (Xu et al. 2018).

The morphology of $\mathrm{Ag}_{2} \mathrm{O}-\mathrm{NPs}$ was examined using SEM as shown in Fig $2 \mathrm{~A}$ and $\mathrm{B}$. The SEM images show husk shaped NPs, indicating that the polyphenols act not only as a reducing agent but also as a capping agent. EDX elemental mapping of Ag was conducted and has been given in Fig $2 \mathrm{C}$. The EDX analysis of NPs has been given in Fig 2D. The chemical elemental study confirms composition Ag and 0. 
Additionally, trace amounts of element $\mathrm{C}$ was also present in NPs. The characteristic signals for $\mathrm{Ag}$ and $\mathrm{O}$ were observed at $3,0.3$ and $0.8 \mathrm{KeV}$ respectively.

The $\mathrm{Ag}_{2} \mathrm{O}-\mathrm{NPs}$ size distribution, NPs surface charge, area, and pore size have been presented in Table 1. It was observed that size distribution of $\mathrm{Ag}_{2} \mathrm{O}-\mathrm{NPs}$ ranges from 20 to $150 \mathrm{~nm}$. The average particle size distribution of $\mathrm{Ag}_{2} \mathrm{O}-\mathrm{NPs}$ was found to be $81 \mathrm{~nm}$. Zeta potential of $\mathrm{Ag}_{2} \mathrm{O}-\mathrm{NPs}$ was detected as a sharp peak at $-67.66 \mathrm{mV}$. This indicated that the NPs surface was negatively charged and value of $-67.66 \mathrm{mV}$ specifies the repulsion among the NPs (Skoglund et al. 2017). The surface area and pore size of $\mathrm{Ag}_{2} \mathrm{O}-$

NPs were found to be $100.21 \mathrm{~m}^{2} / \mathrm{g}$ and $10 \mathrm{~nm}$ respectively. The results depicted that leaf extract mediated NPs have better physicochemical characteristic. Hence, synthesized NPs can be effectively used for abundant biological and environmental applications.

\subsection{Antioxidant and cytotoxicity assay}

The antioxidant capacity of $\mathrm{Ag}_{2} \mathrm{O}-\mathrm{NPs}$ was estimated by DPPH at different concentrations of NPs ranging from 20 to $100 \mu \mathrm{g} / \mathrm{mL}$ (Fig 3). Ascorbic acid was used as standard in this study. It was observed that $61 \%$ inhibition of DPPH activity was observed with aqueous leaf extract at concentration of $150 \mu \mathrm{g}$. This is attributed to the bioactive molecules in the leaf extract element $\mathrm{H}$ specifically donated by $\mathrm{OH}$ reactive groups to eliminate free radicals (Sowndhararajan and Kang 2013). Increase in inhibitory activity from 25 to $91 \pm 1 \%$ was observed for NPs as shown in Fig 3.

Similar findings have been reported in a study by Maheshwaran et al., where $Z$. rosea flower extract mediated $\mathrm{Ag}_{2} \mathrm{O}-\mathrm{NPs}(100 \mu \mathrm{g} / \mathrm{ml})$ showed $73.8 \%$ antioxidant activity thereby confirming the inhibition potential of $\mathrm{Ag}_{2} \mathrm{O}-\mathrm{NPs}$ against reactive oxygen species (ROS) (Maheshwaran et al. 2020). The increase in free-radical-scavenging activity of green amaranth mediated $\mathrm{Ag}_{2} \mathrm{O}-\mathrm{NPs}$ with increasing concentration was equivalent to ascorbic acid. Phytoconstituents such as the phenolic group on the surface of $\mathrm{Ag}_{2} \mathrm{O}$ $\mathrm{NPs}$, with their stable radicals probably confer free radical scavenging activity to the $\mathrm{Ag}_{2} \mathrm{O}-\mathrm{NPs}$. The small size of $\mathrm{Ag}_{2} \mathrm{O}-\mathrm{NPs}$ react readily with the free radicals and thus scavenging is rapid (Skiba 2020). Hence, these $\mathrm{Ag}_{2} \mathrm{O}-\mathrm{NPs}$ have good potential to be used as enhancers in biomedical practices requiring free radical scavenging.

Cell viability assay demonstrated that NPs treated HEK cells showed small reduction in viability (data not shown). HEK cells were viable up to $30 \mu \mathrm{g}$ of $\mathrm{Ag}_{2} \mathrm{O}$ but beyond this concentration viability of HEK cell was greatly decreased, which indicates that in biomedical applications, concentration above $30 \mu \mathrm{g} / \mathrm{mL}$ NPs could be harmful to the non-cancerous cells. Studies by Sukhanova et al., showed that cytotoxicity of NPs depended on chemical and physical properties as well as types of cells used for the toxic study (Sukhanova et al. 2018). Akter et al., reported that Ag-NPs concentrations 5 to $10 \mu \mathrm{g} / \mathrm{mL}$ and sizes from 10 to $100 \mathrm{~nm}$ showed high toxicity in in-vitro studies. Their study also demonstrated that NPs could be stimulate cytotoxicity by the formation of ROS thereby leading to cell death. Different cell lines also expressed different responses to cytotoxic action of Ag-NPs (Akter et al. 2018). 


\subsection{Antibacterial activity}

The bactericidal efficiency of the synthesized $\mathrm{Ag}_{2} \mathrm{O}$ NPs was analyzed using disk diffusion method. The obtained results are shown in Fig. 4 and Table. S1. $\mathrm{Ag}_{2} \mathrm{O}-\mathrm{NPs}$ zone of inhibition increases with increasing concentration of $\mathrm{Ag}_{2} \mathrm{O}-\mathrm{NPs}$ and higher concentrations, the zone of inhibition is equivalent to that observed with the standard antibiotic kanamycin. Synthesized NPs showed higher antibacterial activity as compared to leaf extract (Table S1). Also, at concentration above $30 \mu \mathrm{g}$ NPs exhibited zone of inhibition equivalent to kanamycin. The improved activity of NPs can be attributed to the leaf extract molecules bound to surface NPs which intensely increase the active site of NPs and preventing aggregation of NPs (Iravani et al., 2014). Similarly, MIC results represented that increasing concentration of NPs lead to a decrease in the final bacterial cell concentration. Optimal MIC was determined to be 35 $\mu \mathrm{g} / \mathrm{mL}$ and $45 \mu \mathrm{g} / \mathrm{mL}$ of NPs for $P$. aeruginosa and $S$. aureus respectively (Fig S1).

S. aureus, which is a Gram +ve strain, showed less inhibition due to the existence of thick peptidoglycan cell outer surface, that inhibited the $\mathrm{Ag}_{2} \mathrm{O}-\mathrm{NPs}$ enter into the bacterial cell (Slavin et al. 2017). In contrast, Gram -ve bacteria have a thin peptidoglycan layer, which makes easy for the $\mathrm{Ag}_{2} \mathrm{O}-\mathrm{NPs}$ to enter the bacterial cell leading to cell death, thereby accounting for the higher inhibition for $P$. aeruginosa, a Gram ve strain. It has been reported that bactericidal activity depends upon particle nature and the surface composition of test bacterium. Also, it has been found that bactericidal activity was due to the electrostatic interaction between $\mathrm{Ag}_{2} \mathrm{O}-\mathrm{NPs}$ and the bacteria cell wall. So $\mathrm{Ag}_{2} \mathrm{O}-\mathrm{NPs}$ exhibit higher inhibition ability against $P$. aeruginosa (Jiménez-Tototzintle et al. 2018).

Micrographic pictures of green color fluorescence revealed viable bacterial cells and red color fluorescence imageries show a non-viable cell (Fig 5). Interaction between bacteria cell and NPs resulted in reduced size and count of the bacterial cell and physical rupture of membrane which was observed in the microscopic studies. Reports state that bacterial cell wall surface holds good -ve charge that can interact with Ag+ ions easily and enter inside the cell (D'Lima et al. 2020). After NPs interact and enter into the bacteria cells, cell death is mediated by enzyme inhibition, proteins deactivation, induce oxidative stress, and imbalanced electrolyte and modifies the expression of gene (Shaikh et al. 2019). The results indicate that NPs hold effective bactericidal propensity for Gram - ve than Gram +ve bacteria. In Gram $+v e$ species, thick peptidoglycan layer as an outer membrane function as a penetrability barricade as well susceptible to NPs(Muthukumar et al. 2017).

\subsection{Photocatalytic inactivation of E. coli}

In this study, a Gram -ve bacteria $E$. coli was used as model bacteria since it is an indicator microorganism for faecal contamination. Photocatalytic inactivation of $E$. coli was carried out in the presence of $30 \mu \mathrm{g} \mathrm{ml}^{-1} \mathrm{NPs}$ with and without CFL irradiation and the results are given in Fig 6a. It was observed that highest inactivation of $E$. coli was achieved with $30 \mathrm{\mu g} \mathrm{ml}^{-1}$ of NPs under CFL irradiation within 3 h. Similarly, highest inactivation of $E$. coli was achieved with NPs alone but it took a longer duration ( $>5$ h) but no significant deactivation was achieved with light alone (data not shown). During 
photocatalytic process, photogenerated electron-holes pairs separation and electrons on the surface of NPs can be trapped ROS that improves photocatalytic disinfection (Mcevoy and Zhang 2014). The ROS disrupt the E. coli cell membrane and inhibit the lag phase of bacterial growth. This is followed by attack on DNA structure, proteins and interruption of the replication process leading to cell death (Vietro et al. 2019). Doody et al., found that $\mathrm{Ag}^{+}$ion was $\sim 12$ - and 5-fold toxic to $B$. subtilis and E. coli, respectively than the Ag NPs at same concentrations. Therefore, our experiment notion depicted that the dissolved $\mathrm{Ag}^{+}$ion of synthesized material is more toxic to bacteria $P$. aeruginosa and $S$. aureus. In addition (undissolved) $\mathrm{Ag}_{2} \mathrm{O}$ NPs of equivalent concentrations also show good activity in presence of light (Doody et al. 2016).

\subsection{Photocatalytic degradation of caffeine}

Degradation of caffeine by photocatalytic process was investigated by HPLC analysis. Photocatalytic degradation efficiency of NPs at initial concentration of $50 \mathrm{mg} / \mathrm{L}$ was examined using $50 \mathrm{ppm}$ caffeine at $\mathrm{pH} 9$ for $15 \mathrm{~h}$ under CFL irradiance and data is given in Fig. 6B. The NPs under light irradiance brought about $~ 99 \%$ degradation of $50 \mathrm{ppm}$ caffeine. It was stated that compared to acidic $\mathrm{pH}$ (4.0) and neutral $\mathrm{pH}$ (7.0), alkaline $\mathrm{pH} 9.0$ has a good quantity of hydroxyl ions, which improves caffeine degradation. Thus pH 9.0 was preferred for this study. Previously it has been reported that photocatalytic activities of NPs depend on the physiochemical properties of the photocatalyst (Muthukumar et al. 2020b). Rashmi et al. also showed that Centella asiatica mediated $\mathrm{Ag}_{2} \mathrm{O}-\mathrm{NPs}$ led to the creation of charge carriers and yielded better amount of hydroxyl ions to decolorized AO-8 dye (Rashmi et al. 2020). Creditably, in green amaranth leaf extract mediated $\mathrm{Ag}_{2} \mathrm{O}-\mathrm{NPs}$, the biomolecules bound to $\mathrm{Ag}_{2} \mathrm{O}-\mathrm{NPs}$ and acted as stabilizing agents leading to a larger number of active site NPs. This helps photoelectron to react with many NPs and thereby increases the formation of hydroxyl radical $\left(\mathrm{OH}^{\circ}\right)$ and thus improved degradation. $\mathrm{OH}$ ' was considered as a virtuous oxidizing agent and changed caffeine to toxic less compound than the original harmful contaminant (Jogannatha et al. 2017).

Numerous studies have shown that several materials like $\mathrm{TiO}_{2}$ powder, $\mathrm{ZnO}, \mathrm{AgFeO}_{2}, \mathrm{CeO}_{2}$, and $\mathrm{TiO}_{2} \mathrm{NPs}$ have been used for degradation of caffeine. Other degradative processes such as photo-Fenton, sonocatalytic, adsorption, photolysis, and photocatalytic method have been employed to degrade the caffeine (Palma et al. 2018; Nur Fadzeelah et al. 2019; Muthukumar et al. 2020b). Amongst the caffeine degradation processes reported earlier, photocatalytic method with $\mathrm{NPs}$ using $\mathrm{AgFeO}_{2}$ by facilitated $100 \%$ degradation of caffeine at the high concentrations of $50 \mathrm{ppm}$ and $120 \mathrm{ppm}$ caffeine in synthetic wastewater in 15 and $24 \mathrm{~h}$ respectively (Muthukumar et al. 2020b). Similar finding was obtained in our study, where $\mathrm{Ag}_{2} \mathrm{O}-\mathrm{NPs}$ at $50 \mathrm{mg} / \mathrm{L}$ concentration brought about $100 \%$ degradation of caffeine within 15 h. This highlights the potential of synthesized NPs to be used for degrading harmful organic contaminants by an eco-friendly approach. Possible mechanism of synthesized NPs photocatalytic degradation and inactivation of caffeine and E. coli have been shown in Fig. S2.

\section{Conclusions}


The green amaranth aqueous leaf extract interceded $\mathrm{Ag}^{0} / \mathrm{Ag}_{2} \mathrm{O}-\mathrm{NPs}$ were successfully synthesized and the antimicrobial and antioxidant properties were investigated along with studies on photocatalytic inactivation of $E$. coli and degradation of caffeine using these nanoparticles. Analytical techniques confirmed that NPs have husk shape with cubic phase structure, large surface, less aggregation and smaller sizes and these properties made it as a better physicochemical nanomaterial. As well, trace of $\mathrm{Ag}^{0}$ in the sample has been identified by XPS. Studies on antibacterial aspects showed that synthesized NPs were more effective on Gram -ve than Gram +ve bacteria. Also, antioxidant efficacy of the NPs (100 $\mu \mathrm{g}$ ) was equivalent to the ascorbic acid. HPLC investigated the photocatalytic degradation of NPs and it was found that caffeine by $50 \mathrm{mg} / \mathrm{L}$ of NPs samples brought about $99 \%$ degradation of caffeine at 50 ppm initial concentration. Moreover, NPs under optimized conditions exhibited effective and rapid photocatalytic inactivation of E. coli. These results suggest that synthesized NPs photocatalyst prove to be an eco-friendly method for removal of organic contaminants and inactivation of harmful microbes in the environment.

\section{Declarations}

The authors declare that they have no known competing financial interests or personal

relationships that could have appeared to influence the work reported in this paper.

\section{Funding}

The present study was carried out by the financial supported by SERB-DST under

National Post-Doctoral Fellowship vide SO. No: PDF/2018/000795.

\section{Credit authorship contribution statement}

Harshiny Muthukumar: Conceptualization, Methodology, Formal analysis, Investigation,

Validation and Writing-Original draft, review \& editing.

Manoj Kumar, P. Santosh Kumar, A. Pugazhendhi - Methodology. review and editing

Sathyanarayana N Gummadi: Conceptualization, Resources, Methodology, Supervision and

Writing-original draft, review and editing.

\section{Acknowledgement}

The authors would like to acknowledge IIT Madras for the research facilities. SKP and MKS would like to thank MHRD and IIT Madras for the fellowship. MH acknowledges SERB-DST for the National PostDoctoral Fellowship (SO. No: PDF/2018/000795). Authors would like to acknowledge SAIF-IIT Madras for 
characterization studies. MH thank Dr. Swathi Sucharita Dash for their helpful comments on the manuscript.

\section{References}

Ahmed S, Ahmad M, Swami BL, Ikram S (2016) A review on plants extract mediated synthesis of silver nanoparticles for antimicrobial applications: A green expertise. J. Adv. Res. 7:17-28.

https://doi.org/10.1016/j.jare.2015.02.007

Aiswarya Devi S, Harshiny M, Udaykumar S, et al (2017) Strategy of metal iron doping and greenmediated ZnO nanoparticles: Dissolubility, antibacterial and cytotoxic traits. Toxicol. Res. 6:854-865. https://doi.org/10.1039/c7tx00093f

Akter M, Sikder T, Rahman M, et al (2018) A systematic review on silver nanoparticles-induced cytotoxicity: Physicochemical properties and perspectives. J. Adv. Res. 9:1-16. https://doi.org/10.1016/j.jare.2017.10.008

D'Lima L, Phadke M, Ashok VD (2020) Biogenic silver and silver oxide hybrid nanoparticles: A potential antimicrobial against multi drug-resistant: Pseudomonas aeruginosa. New. J. Chem. 44:4935-4941. https://doi.org/10.1039/c9nj04216d

Doody MA, Wang D, Bais HP, Jin Y (2016) Differential antimicrobial activity of silver nanoparticles to bacteria Bacillus subtilis and Escherichia coli , and toxicity to crop plant Zea mays and beneficial B . subtilis -inoculated. J Nanopart Res. https://doi.org/10.1007/s11051-016-3602-z

Elemike EE, Onwudiwe DC, Ekennia AC, et al (2017) Green synthesis of $\mathrm{Ag} / \mathrm{Ag}_{2} \mathrm{O}$ nanoparticles using aqueous leaf extract of Eupatorium odoratum and its antimicrobial and mosquito larvicidal activities. Molecules 22:1-15. https://doi.org/10.3390/molecules22050674

Ganguly P, Byrne C, Breen A, Pillai SC (2018) Antimicrobial activity of photocatalysts: Fundamentals, mechanisms, kinetics and recent advances. Appl. Catal. B-Environ 225:51-75.

https://doi.org/10.1016/j.apcatb.2017.11.018

Iravani, S, Korbekandi, H, Mirmohammadi, SV, Zolfaghari B (2014) Synthesis of silver nanoparticles: chemical, physical and biological methods. Res Pharm Sci 9:385-406

Jiang W, Wang X, Wu Z, et al (2015) Silver oxide as superb and stable photocatalyst under visible and near-infrared light irradiation and its photocatalytic mechanism. Ind. Eng. Chem. Res 54:832-841. https://doi.org/10.1021/ie503241k

Jiménez-Tototzintle M, Ferreira IJ, da Silva Duque S, et al (2018) Removal of contaminants of emerging concern (CECs) and antibiotic resistant bacteria in urban wastewater using UVA/TiO2/H2O2 photocatalysis. Chemosphere 210:449-457. https:// doi.org/10.1016/j.chemosphere.2018.07.036 
Jogannatha RB, Ramu SR, Padaki M, Balakrishna RG (2017) An efficient method for the synthesis of photo catalytically active $\mathrm{ZnO}$ nanoparticles by a gel-combustion method for the photo- degradation of Caffeine. Nanochem Res 2:1-10. https://doi.org/10.22036/ncr.2017.01.008

Kahru A, Dubourguier HC (2010) From ecotoxicology to nanoecotoxicology. Toxicology 269:105-119. https://doi.org/10.1016/j.tox.2009.08.016

Maheshwaran G, Nivedhitha Bharathi A, Malai Selvi M, et al (2020) Green synthesis of Silver oxide nanoparticles using Zephyranthes Rosea flower extract and evaluation of biological activities. J. Environ. Chem. Eng. 8:104137. https://doi.org/10.1016/j.jece.2020.104137

Mcevoy JG, Zhang Z (2014) Antimicrobial and photocatalytic disinfection mechanisms in silver-modified photocatalysts under dark and light conditions. J. Photochem. Photobiol. C" 19:62-75. https://doi.org/10.1016/j.jphotochemrev.2014.01.001

Muthukumar H, Chandrasekaran NI, Naina Mohammed S, et al (2017) Iron oxide nano-material: physicochemical traits and in vitro antibacterial propensity against multidrug resistant bacteria. $\mathrm{J}$ Ind Eng Chem 45:121-130. https://doi.org/10.1016/j.jiec.2016.09.014

Muthukumar H, Matheswaran M (2015) Amaranthus spinosus leaf extract mediated feo nanoparticles: physicochemical traits, photocatalytic and antioxidant activity. ACS Sustain Chem Eng. 3:3149-3156. https://doi.org/10.1021/acssuschemeng.5b00722

Muthukumar H, Palanirajan SK, Shanmugam MK, Gummadi SN (2020a) Plant extract mediated synthesis enhanced the functional properties of silver ferrite nanoparticles over chemical mediated synthesis.

Biotechnol Rep. 26:e00469. https://doi.org/10.1016/j.btre.2020.e00469

Muthukumar H, Shanmugam MK, Gummadi SN (2020b) Caffeine degradation in synthetic coffee wastewater using silverferrite nanoparticles fabricated via green route using Amaranthus blitum leaf aqueous extract. J Water Process Eng. 36:101382. https://doi.org/10.1016/j.jwpe.2020.101382

Nel AE, George S, Pokhrel S, et al (2010) Use of a Rapid Cytotoxicity Screening Approach To Engineer a Safer Zinc Oxide Nanoparticle through Iron Doping. Acs Nano 4:15-29. https://doi.org/Doi $10.1021 / \mathrm{Nn} 901503 \mathrm{q}$

Nur Fadzeelah AK, Abdullah AZ, Zubir NA, et al (2019) Sonocatalytic degradation of caffeine using $\mathrm{CeO}_{2}$ catalyst: Parametric and reusability studies. J. Phys. Conf. Ser 1349:. https://doi.org/10.1088/1742$6596 / 1349 / 1 / 012147$

Palma D, Prevot AB, Brigante $M$, et al (2018) New insights on the photodegradation of caffeine in the presence of bio-based substances-magnetic iron oxide hybrid nanomaterials. Materials 11:1-17. https://doi.org/10.3390/ma11071084 
Palomares RI, Navarro RE, Urbina RH, et al (2013) León, E. R., Tánori, J., and Synthesis of silver nanoparticles using reducing agents obtained from natural sources (Rumex hymenosepalus extracts). Nanoscale. Res. Lett. . 8 SRC-G:318-326

Pang Z, Raudonis R, Glick BR, et al (2019) Antibiotic resistance in Pseudomonas aeruginosa: mechanisms and alternative therapeutic strategies. Biotechnol. Adv. 37:177-192. https://doi.org/10.1016/j.biotechadv.2018.11.013

Pugazhendhi A, Prabakar D, Jacob JM, et al (2018) Synthesis and characterization of silver nanoparticles using Gelidium amansii and its antimicrobial property against various pathogenic bacteria. Microb. Pathog. 114:41-45. https://doi.org/10.1016/j.micpath.2017.11.013

Rashmi BN, Harlapur SF, Avinash B, et al (2020) Facile green synthesis of silver oxide nanoparticles and their electrochemical , photocatalytic and biological studies. Inorg. Chem. Commun. 111:107580. https://doi.org/10.1016/j.inoche.2019.107580

Ravichandran S, Paluri V, Kumar G, et al (2016) A novel approach for the biosynthesis of silver oxide nanoparticles using aqueous leaf extract of Callistemon lanceolatus (Myrtaceae) and their therapeutic potential. J.Exp. Nanosci. 11:445-458. https://doi.org/10.1080/17458080.2015.1077534

Ren J, Wang W, Zhang L, et al (2009) Photocatalytic inactivation of bacteria by photocatalyst Bi2 $\mathrm{WO}_{6}$ under visible light. Catal. Commun. 10:1940-1943. https://doi.org/10.1016/j.catcom.2009.07.006

Rokade AA, Patil MP, Yoo S II, et al (2016) Pure green chemical approach for synthesis of $\mathrm{Ag}_{2} \mathrm{O}$ nanoparticles. Green Chem Lett Rev s 9:216-222. https://doi.org/10.1080/17518253.2016.1234005

Roy A, Bulut O, Some S, et al (2019) Green synthesis of silver nanoparticles: Biomolecule-nanoparticle organizations targeting antimicrobial activity. RSC Advances 9:2673-2702. https://doi.org/10.1039/c8ra08982e

Schröfel A, Kratošová G, Šafařík I, et al (2014) Applications of biosynthesized metallic nanoparticles - A review. Acta Biomaterialia 10:4023-4042. https://doi.org/10.1016/j.actbio.2014.05.022

Shaikh S, Nazam N, Rizvi SMD, et al (2019) Mechanistic insights into the antimicrobial actions of metallic nanoparticles and their implications for multidrug resistance. Int. J. Mol. Sci. 20:1-15. https://doi.org/10.3390/ijms20102468

Shanmuganathan R, MubarakAli D, Prabakar D, et al (2018) An enhancement of antimicrobial efficacy of biogenic and ceftriaxone-conjugated silver nanoparticles: green approach. Environ. Sci. Pollut. Res. 25:10362-10370. https://doi.org/10.1007/s11356-017-9367-9

Siddiqi KS, Husen A, Rao RAK (2018) A review on biosynthesis of silver nanoparticles and their biocidal properties. J. Nanobiotechnology, 16:. https://doi.org/10.1186/s12951-018-0334-5 
Skiba VVGVM (2020) Eco - friendly " green " synthesis of silver nanoparticles with the black currant pomace extract and its antibacterial, electrochemical, and antioxidant activity. Appl. Nanosci. https://doi.org/10.1007/s13204-020-01369-z

Skoglund S, Blomberg E, Wallinder IO, et al (2017) A novel explanation for the enhanced colloidal stability of silver nanoparticles in the presence of an oppositely charged surfactant. Phys. Chem. Chem. Phys. 19:28037-28043. https://doi.org/10.1039/c7cp04662f

Slavin YN, Asnis J, Häfeli UO, Bach H (2017) Metal nanoparticles: Understanding the mechanisms behind antibacterial activity. J. Nanobiotechnology. 15:1-20. https://doi.org/10.1186/s12951-017-0308-z

Sowndhararajan K, Kang SC (2013) Free radical scavenging activity from different extracts of leaves of Bauhinia vahlii Wight \& Arn. Saudi J. Biol. Sci. 20:319-325. https://doi.org/10.1016/j.sjbs.2012.12.005

Sukhanova A, Bozrova S, Sokolov P, et al (2018) Dependence of Nanoparticle Toxicity on Their Physical and Chemical Properties. Nanoscale Res. Lett. 13:. https://doi.org/10.1186/s11671-018-2457-x

Taylor, TA, Unakal C (2019) Staphylococcus Aureus. In: Taylor TA, Unakal CG

Thiyagarajan K, Bharti VK, Tyagi S, et al (2018) Synthesis of non-toxic, biocompatible, and colloidal stable silver nanoparticle using egg-white protein as capping and reducing agents for sustainable antibacterial application. RSC Adv. 8:23213-23229. https://doi.org/10.1039/C8RA03649G

Vietro N De, Tursi A, Beneduci A (2019) Photocatalytic inactivation of Escherichia coli bacteria in water using low pressure plasma. Photochem. Photobiol. Sci.18: 2248-2258.

https://doi.org/10.1039/c9pp00050j

Wang W, Arshad MI, Khurshid M, et al (2018) Antibiotic resistance: a rundown of a global crisis. Infect. Drug. Resist. 1645-1658

Xu H, Xie J, Jia W, et al (2018) The formation of visible light-driven $\mathrm{Ag} / \mathrm{Ag}_{2} \mathrm{O}$ photocatalyst with excellent property of photocatalytic activity and photocorrosion inhibition. J Colloid Interf Sci. 516:511521. https://doi.org/10.1016/j.jcis.2018.01.071

Yang ZH, Ho CH, Lee S (2015) Plasma-induced formation of flower-like $\mathrm{Ag}_{2} \mathrm{O}$ nanostructures. Appl. Surf. Sci. 349:609-614. https://doi.org/10.1016/j.apsusc.2015.05.055

\section{Table}

Table 1. Zeta potential, particle size and surface area, pore size of $\mathrm{Ag}_{2} \mathrm{O}$ NPs. 


\begin{tabular}{llllll}
\hline NPs & $\begin{array}{l}\text { Zeta } \\
\text { potential } \\
(\mathrm{mV})\end{array}$ & $\begin{array}{l}\text { Particle size } \\
(\mathrm{nm})\end{array}$ & $\begin{array}{l}\text { Surface area } \\
\left(\mathrm{m}^{2} / \mathrm{g}\right)\end{array}$ & $\begin{array}{l}\text { Pore size } \\
(\mathrm{nm})\end{array}$ & $\begin{array}{l}\text { Structure } \\
\end{array}$ \\
\hline $\mathrm{Ag}_{2} \mathrm{O}$ & -67.66 & 81 & 100.21 & 10 & cubic \\
\hline
\end{tabular}

Figures
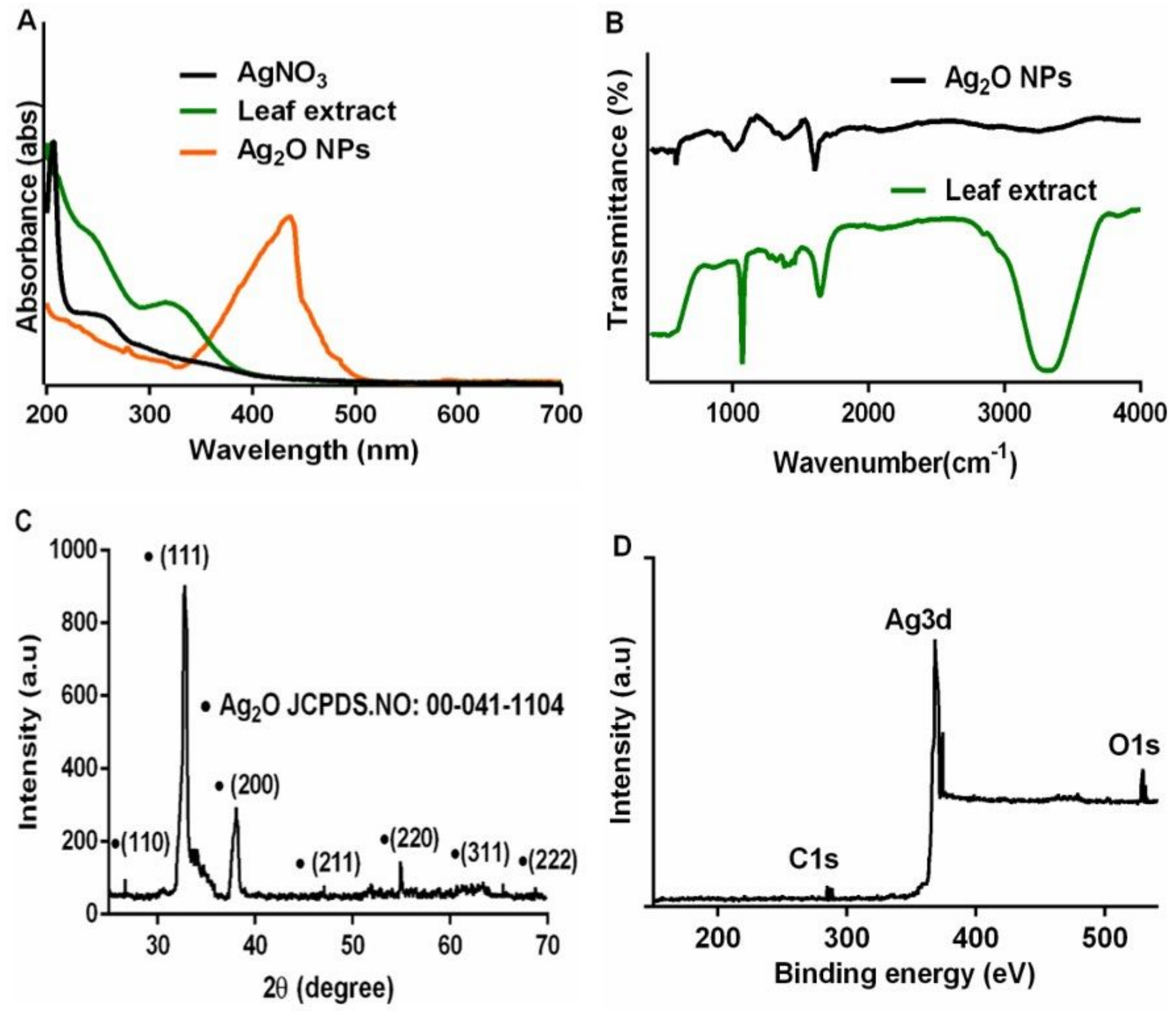

Figure 1 
Spectral analysis of green amaranth aqueous leaf extract, AgNO3, Ag2O NPs. (A) Comparison of precursor and Ag20 NPs UV-Vis analysis. The samples were scanned from $200 \mathrm{~nm}$ to $900 \mathrm{~nm}$ in $1.00 \mathrm{~cm}$ path length cuvettes. (B) FTIR spectral analysis of leaf extract and Ag2O NPs obtained over the range of $400-4000 \mathrm{~cm}-1$ with a resolution of $4 \mathrm{~cm}-1$ at room temperature. (C) XRD pattern of Ag20 NPs and Diffractogram of NPs also corresponded to JCPDS card no:00-041-1104 AgFe02. (D) XPS survey spectrum of Ag20 NPs
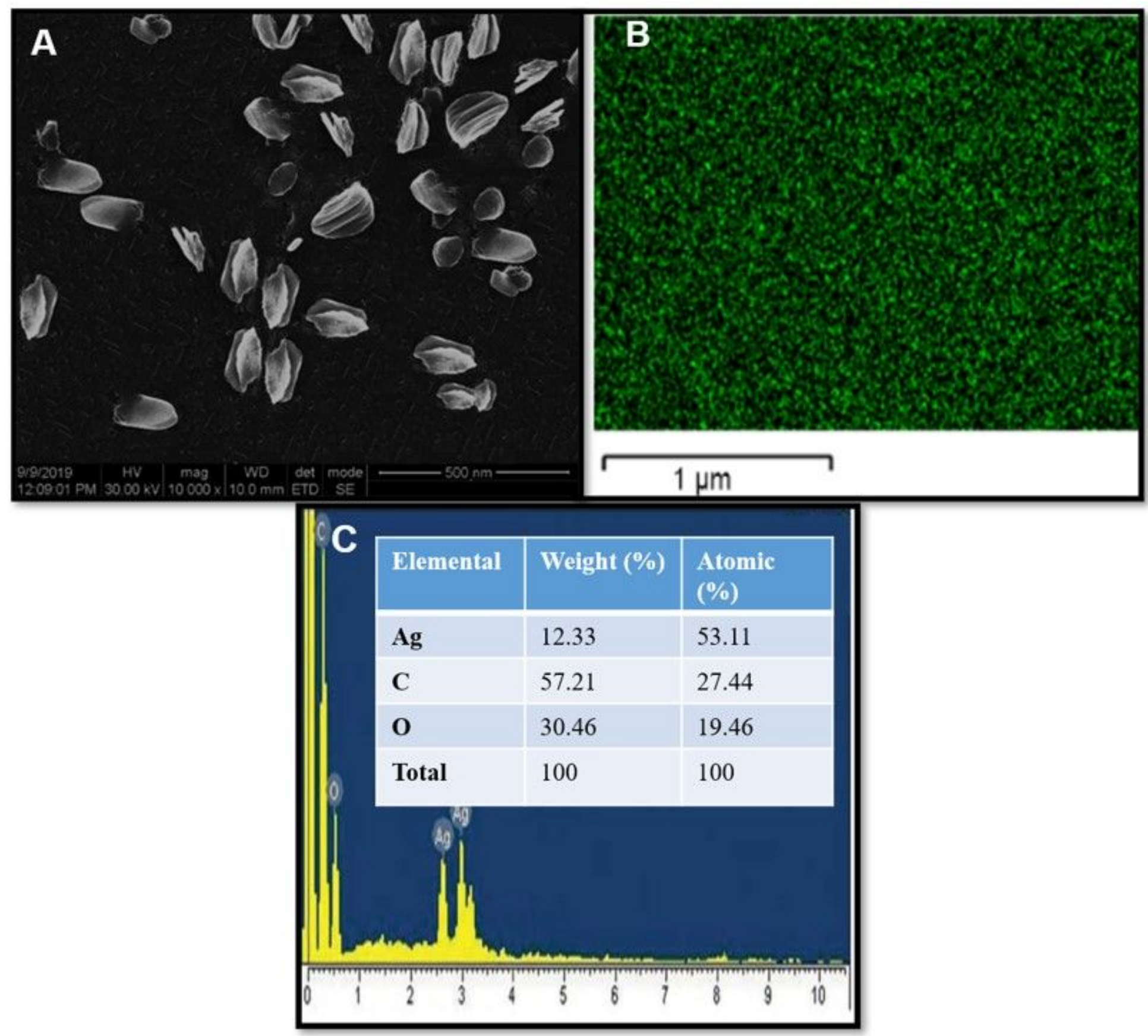

\section{Figure 2}

Scanning electron micrograph of synthesized NPs (A, B) SEM images of Ag20 NPs at 500 and $50 \mathrm{~nm}$ resolution respectively, EDX elemental analysis (C) Ag element mapping image and SEM operating at a voltage of $30 \mathrm{keV}(\mathrm{D})$ corresponding energy dispersive X-ray spectra of NPs. 


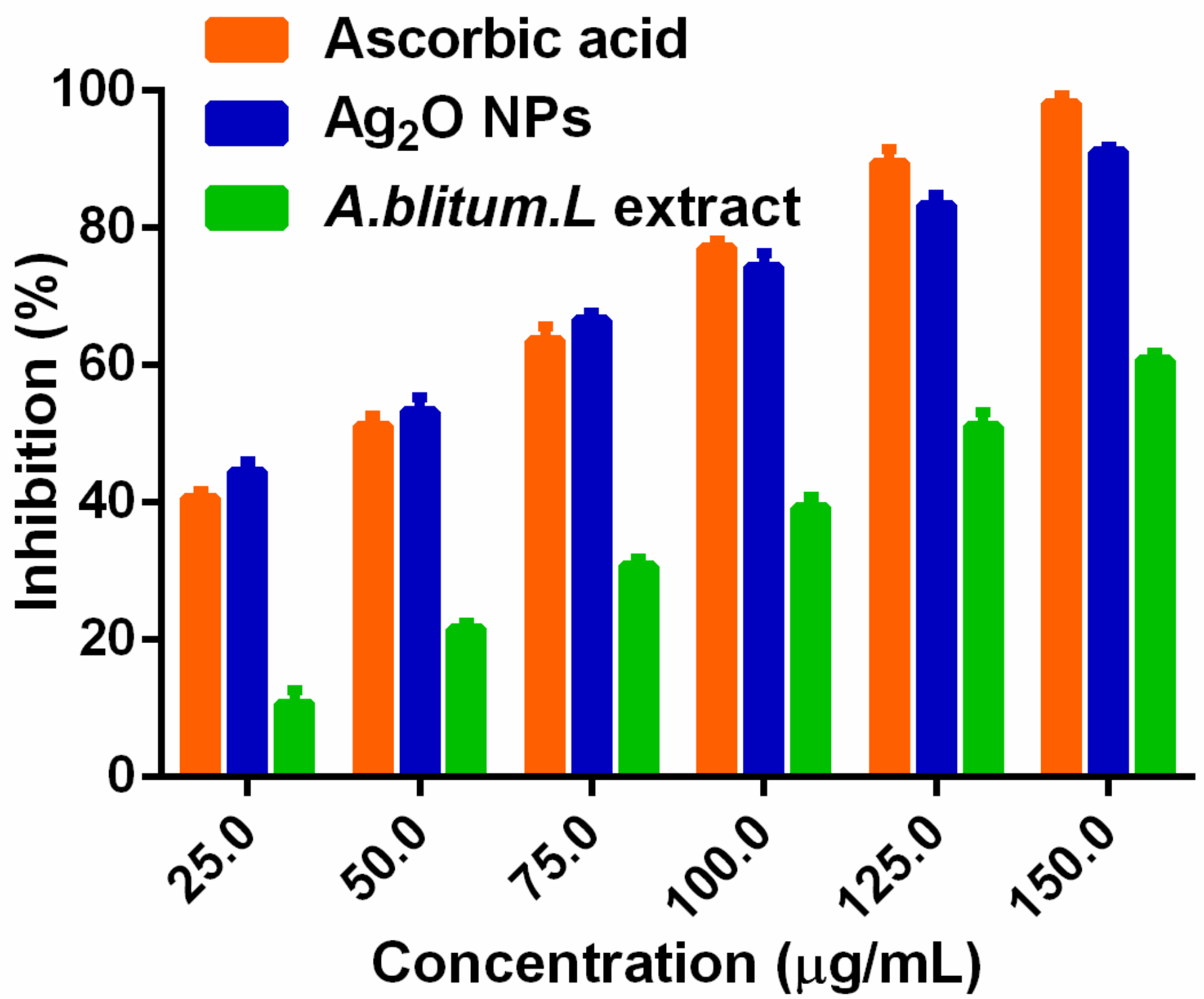

Figure 3

Antioxidant activity by DPPH radical scavenging assay. DPPH scavenging activity of Ag20 NPs compared with the standard ascorbic acid and prepared leaf extract. Results are representative of three replicates and error bars represent standard deviation. One-way ANOVAs were performed to evaluate significance comparing the both NPs to the control. A value of $p<0.0001$ was considered to be statistically significant as compared to the control. 

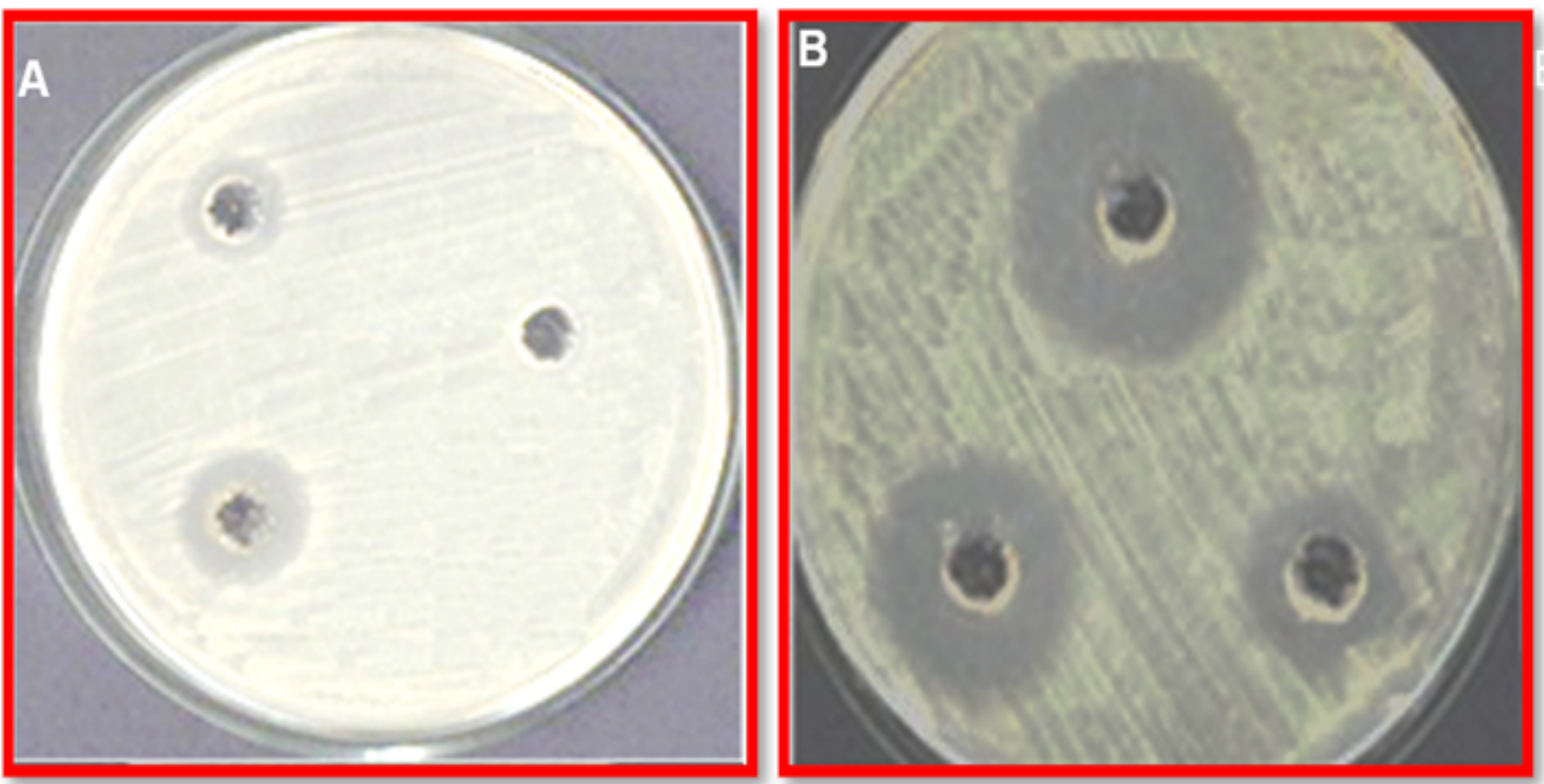

Figure 4

Zone of inhibition (mm) against (A) Staphylococcus aureus and (B) Pseudomonas aeruginosa by disc diffusion and various concentration $(10,20$ and $30 \mu \mathrm{g})$ of NPs. 

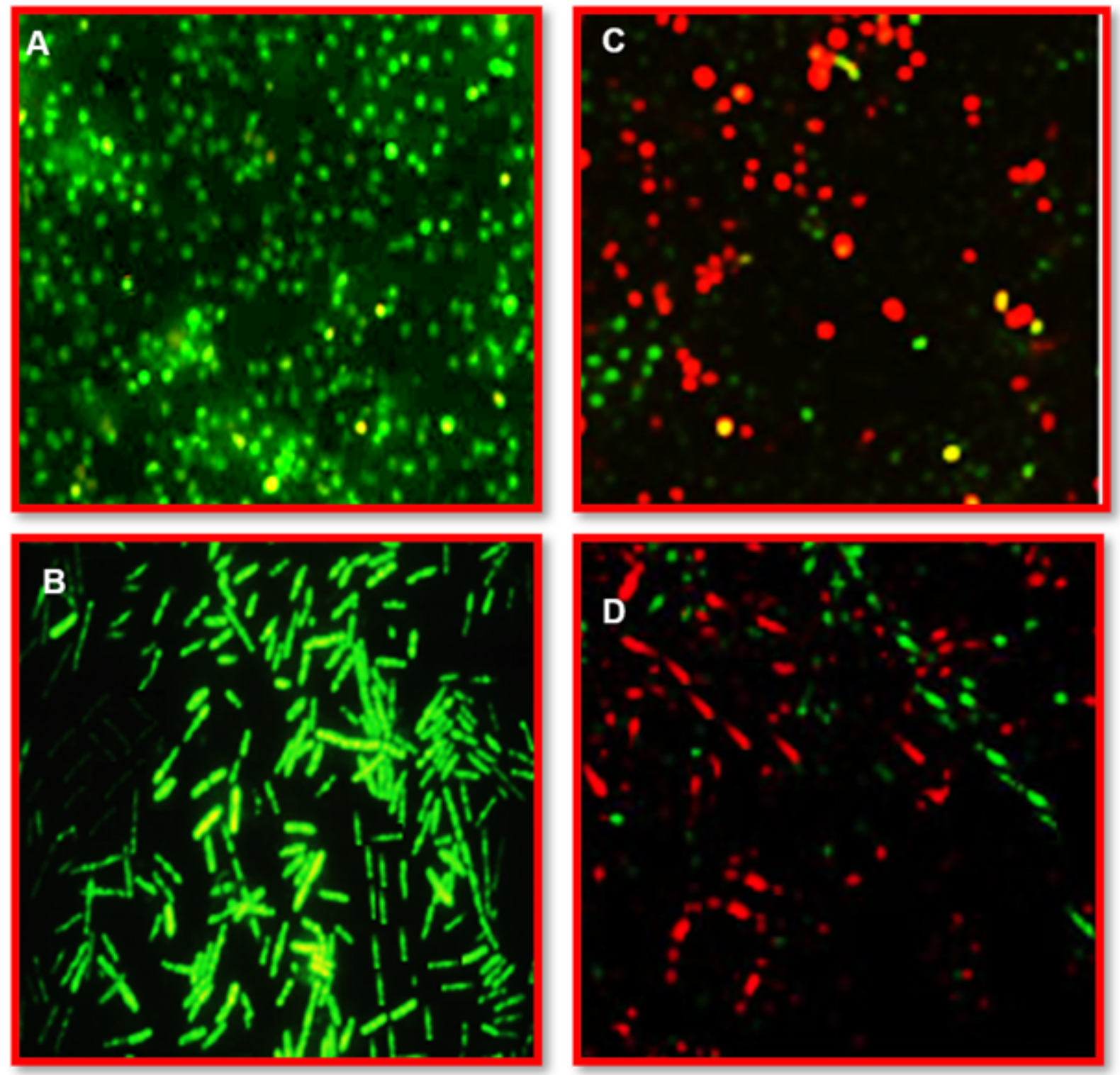

\section{Figure 5}

Live/ dead staining of S. aureus and P. aeruginosa exposed to NPs, (A, B) Non-treated test species S. aureus and $P$. aeruginosa, $(C, D)$ test species $S$. aureus and $P$. aeruginosa were exposed to Ag2O NPs microscopic images at magnification of $5 \mu \mathrm{m}$. 

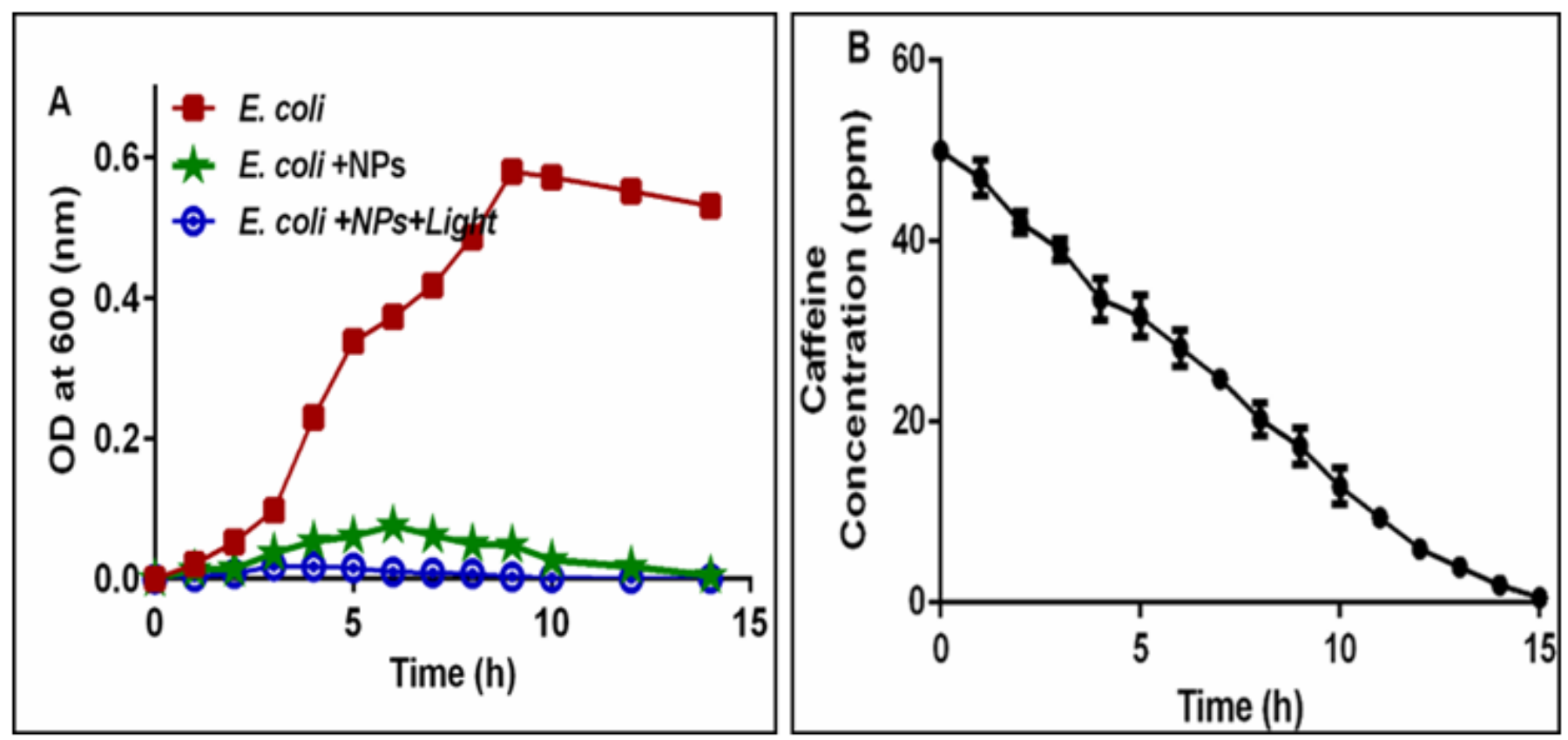

Figure 6

Photocatalytic inactivation of E. coli and photocatalytic degradation of caffeine. (A) E. coli control growth curve and inactivation by synthesised NPs under light and dark condition. (B) The degradation $n$ efficiency of Ag2O NPs on 50 ppm caffeine at pH9 under compact fluorescent lamp illumination condition in the presence of $50 \mathrm{mg} / \mathrm{L}$.

\section{Supplementary Files}

This is a list of supplementary files associated with this preprint. Click to download.

- GraphicalabstractsilveroxideJHM.docx

- SupplementraysilveroxideJHM.docx 